\title{
Metoda Simulasi Bagi Perhitungan Kebutuhan Jumlah Tempat Duduk Pada Fasilitas Reservasi Tiket
}

\section{Simulation Method for Calculating Number of Seat Needed for Ticket Reservation Facilities}

\author{
Anita Susanti $^{1, a)}$, Ria Asih Aryani Soemitro ${ }^{2, b)}$ \& Hitapriya Suprayitno ${ }^{3, c)}$ \\ ${ }^{1)}$ Mahasiswa Teknik Sipil, Institut Teknologi Sepuluh Nopember, Surabaya \\ ${ }^{2)}$ Departemen Teknik Sipil, Institut Teknologi Sepuluh Nopember, Surabaya \\ ${ }^{3)}$ Departemen Teknik Sipil, Institut Teknologi Sepuluh Nopember, Surabaya
}

Koresponden : a)anitasusanti.pasmar@gmail.com, b) soemitroraa@gmail.com \&

c)suprayitno.hita@gmail.com

\begin{abstract}
ABSTRAK
Infrastruktur adalah komponen penting yang harus direncanakan, dirancang, dibangun, dan dikelola dengan baik sesuai dengan prinsip-prinsip Manajemen Aset Infrastruktur. Salah satu komponen penting pada stasiun kereta api adalah fasilitas untuk reservasi tiket yang perlu dirancang dengan baik dan memerlukan adanya metoda simulasi. Metoda simulasi ini sangat penting untuk dilakukan guna mnegetahui kebutuhan jumlah tempat duduk bagi pemesan tiket kereta api. Oleh karena itu diperlukan penelitian mengenai metoda simulasi perhitungan kebutuhan jumlah tempat duduk pada fasilitas reservasi tiket kereta api. Metode yang dilakukan pada metoda simulasi ini adalah pengumpulan data sekunder dan data primer. Penelitian menghasilkan metoda simulasi bagi perhitungan kebutuhan jumlah tempat duduk berdasarkan data asumsi. Metoda simulasi yang dihasilkan sudah baik. Distribusi headway ditentukan mengikuti Distribusi Poisson dengan $\lambda$ sebesar 3 menit. Distribusi waktu pengambilan tiket ditentukan mengikuti Distribusi Titik dengan $\mathrm{t}$ sebesar 1 menit. Distribusi waktu pengisian formulir ditentukan mengikuti Distribusi Normal dengan $\mu$ sebesar 4 menit. Distribusi waktu dilayani di loket ditentukan mengikuti Distribusi Normal dengan $\mu$ sebesar 7 menit. Jumlah tempat duduk yang harus disediakan bagi 20 orang reservasi tiket kereta api sejumlah 2 tempat duduk.
\end{abstract}

Kata Kunci : manajemen aset infrastruktur, stasiun kereta api, metoda simulasi, tempat duduk

\section{PENDAHULUAN}

Infrastruktur adalah komponen penting yang harus direncanakan, dirancang, dibangun, dan dikelola dengan baik sesuai dengan prinsip-prinsip Manajemen Aset Infrastruktur. Salah satu infrastruktur transportasi yang penting adalah stasiun kereta api. Stasiun kereta api adalah tempat untuk menaikkan dan menurunkan penumpang. Perbedaan jumlah penumpang yang naik dan turun di tiap-tiap stasiun dipengaruhi oleh adanya pemanfaatan guna lahan yang berbeda-beda di tiap-tiap stasiun tersebut. Kemudahan menjangkau lokasi stasiun dan didukung dengan adanya ketersediaan fasilitas yang memadai merupakan daya tarik tersendiri untuk menarik minat masyarakat menggunakan layanan kereta api (KA). Jenis-jenis fasilitas yang harus disediakan oleh pihak pengelola stasiun KA adalah parkir kendaraan, loket penjualan tiket, jumlah tempat duduk, toilet, jadwal 
keberangkatan dan kedatangan, fasilitas konektivitas dan adanya layanan angkutan umum pengumpan di sekitar stasiun.

Ketersediaan fasilitas baik di dalam maupun di luar stasiun harus disediakan dengan baik sesuai dengan keinginan penggunanya. Hal tersebut penting dilakukan agar permasalahan transportasi seperti halnya antrian panjang pada saat proses reservasi tiket KA dapat diminimalkan. Permasalahan transportasi yang memiliki sifat ketidakpastian tersebut membutuhkan adanya suatu model simulasi sebagai dasar perencanaan penyelesaian permasalahan sebelum diimplementasikan (Butar Butar \& Yamin, 2008).

Model simulasi tersebut penting dilakukan untuk menyelesaikan salah satu permasalahan terkait kebutuhan fasilitas reservasi tiket KA. Jenis-jenis fasilitas yang terkait dengan reservasi tiket KA adalah jumlah pos pengambilan tiket, jumlah pos pengisian formulir, jumlah tempat duduk dan jumlah loket kira-kira harus disesuaikan dengan jumlah orang yang melakukan pemesanan tiket KA. Kebutuhan jumlah tempat duduk sangat berkaitan dengan kenyamanan bagi pemesan tiket KA terutama pada saat terjadinya antrian panjang. Oleh karena itu diperlukan penelitian mengenai metoda simulasi bagi perhitungan kebutuhan jumlah tempat duduk pada fasilitas reservasi tiket. Penulisan penelitian ini bertujuan untuk membahas metoda simulasi yang tepat pada perhitungan kebutuhan jumlah tempat duduk pada saat proses reservasi tiket KA dari data perencanaan/data fiktif.

\section{STUDI PUSTAKA}

\section{Definisi Simulasi}

Simulasi adalah upaya untuk menduplikasi fitur, tampilan dan karakteristik sistem yang sebenarnya (Heizer \& Render, 2008). Model simulasi adalah perencanaan perhitungan dengan bantuan program komputer sebelum perencanaan di implementasikan. Simulasi dapat membantu menyelesaikan permasalahan transportasi, yaitu: 1). Meminimalkan jumlah antrian; 2). Menentukan durasi traffic light; 3). Menentukan waktu keberangkatan dan kedatangan bus pada shelter; 4). Menentukan jumlah optimal bus untuk suatu trayek; 5). Menentukan trayek optimum; 6). Menentukan penjadwalan bus (Butar \& Yamin, 2008).

\section{Definisi Distribusi Peluang}

Distribusi peluang adalah cara untuk mengukur adanya peluang dari suatu peristiwa yang terjadi dan terdiri dari variabel acak yaitu diskrit dan kontinyu. Distribusi peluang dengan variabel acak adalah distribusi distribusi peluang Binomial dan distribusi peluang Poisson. Distribusi dengan variabek acak kontinyu adalah distribusi peluang Normal, distribusi-t dan distribusi chi-kuadrat (Sudjana, 2004).

\section{Distribusi Peluang Normal}

Distribusi Normal merupakan distribusi kontinyu yang paling penting dalam bidang statistik karena dapat mewakili kumpulan data observasi yang terjadi dalam alam semesta, industri, maupun penelitian (Dimyati dkk, 1994). Distribusi Normal memiliki dua parameter yaitu mean $(\mu)$ dan simpangan baku $(\sigma)$ (Sudjana, 2004). Gambar 1 menunjukkan grafik Distribusi Normal.

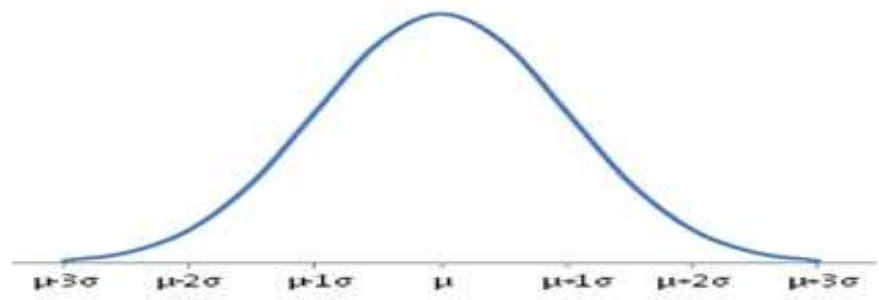

Gambar 1. Grafik Distribusi Normal 


\section{Distribusi Peluang Poisson}

Distribusi Poisson dapat dianggap sebagai pendekatan pada distribusi Binomial apabila banyaknya $\mathrm{N}$ sangat besar dan peluang $\pi$ terjadinya peristiwa dalam percobaan yang tunggal saangat kecil, sedemikian hasil $N \pi$ nilainya tetap. Nilai tetap ini biasa dinyatakan dengan $\lambda=\mathrm{N} \pi$ dan merupakan parameter untuk distribusi Poisson (Sudjana, 2004). Grafik distribusi Poisson sangat berkaitan dengan kedatangan pelanggan ke suatu tempat (Zulfikarijah, 2004) dan ditunjukkan pada gambar 2.

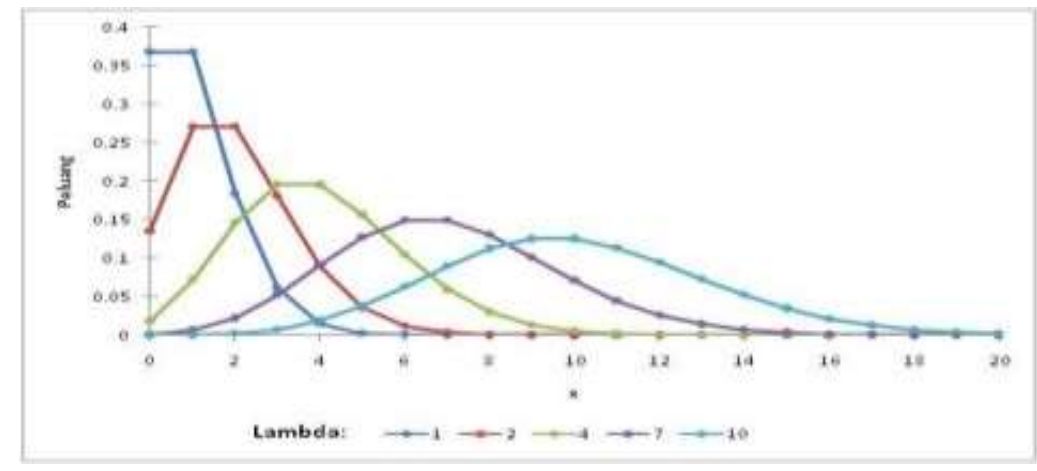

Gambar 2. Grafik Distribusi Poisson

\section{Distribusi Peluang Titik}

Distribusi Titik adalah distribusi yang paling sederhana yang kemungkinan munculnya setiap bilangan adalah sama. Grafik distribusi Titik ditunjukkan pada gambar 3.

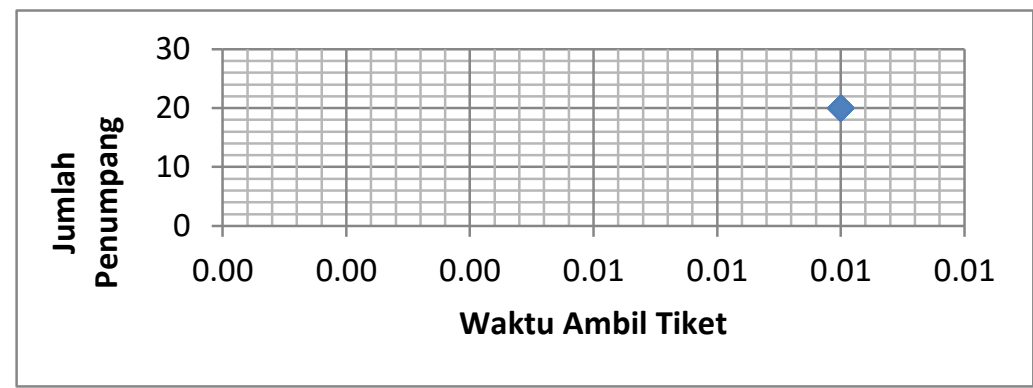

Gambar 3. Grafik Distribusi Titik

\section{Microsoft Excel}

Microsoft excel adalah software microsoft yang digunakan untuk mengolah data, terutama yang berhubungan dengan angka. Secara garis besar formula pada aplikasi excel adalah suatu persamaan matematika untuk menghitung nilai-nilai tertentu dengan tujuan mendapatkan hasil yang diharapkan.

\section{Fungsi IF (Logika)}

Fungsi IF adalah fungsi logika yang paling banyak diaplikasikan, terutama dalam penerapan formula lanjutan yang melibatkan banyak data dan keputusan bercabang. Fungsi IF akan mengambil suatu kondisi tertentu dan menetukan nilai "TRUE" atau "FALSE. Fungsi IF dapat digunakan dengan formula yang ditunjukkan pada tabel 1. 
Tabel 1. Contoh Fungsi IF ((Fx = IF (E5>70;”Lulus;Tidak Lulus"))

\begin{tabular}{ccc}
\hline D & E & F \\
\hline Nama & Nilai & Hasil \\
Muhammad & 70 & Tidak Lulus \\
Fatchul & 80 & Lulus \\
Hidayat & 90 & Lulus \\
\hline
\end{tabular}

\section{Fungsi Randbetween} berbeda.

Fungsi randbetween adalah untuk membangkitkan bilangan acak antara dua nilai yang

\section{PENGUMPULAN DATA}

Metode yang digunakan pada metoda simulasi perhitungan tempat duduk ini adalah pengumpulan data sekunder terkait literatur dan pengumpulan data primer terkait proses reservasi tiket kereta api (KA). Pada pengumpulan data primer dilakukan pengamatan secara langsung di Stasiun Gubeng untuk mengetahui proses pemesanan tiket kereta api yang dijadikan acuan atau dasar dalam mengerjakan metoda simulasi.

\section{ANALISIS PENELITAN}

\section{Proses Simulasi Pemesanan Tiket Kereta Api}

Proses simulasi perhitungan tempat duduk bagi reservasi tiket kereta api (KA) harus melalui beberapa tahapan. Tahapan-tahapan yang harus dilalui mulai dari datang/masuk (IN) sampai dengan keluar (OUT) adalah sebagai berikut: 1). Pos pengambilan tiket, 2). Pos pengisian formulir, 3). Proses loket kosong, apabila loket penuh harus duduk terlebih dahulu dan apabila loket kosong dapat langsung dilayani. Tahapan-tahapan yang harus dilalui oleh pemesan tiket kereta api dapat ditunjukkan pada gambar 4.

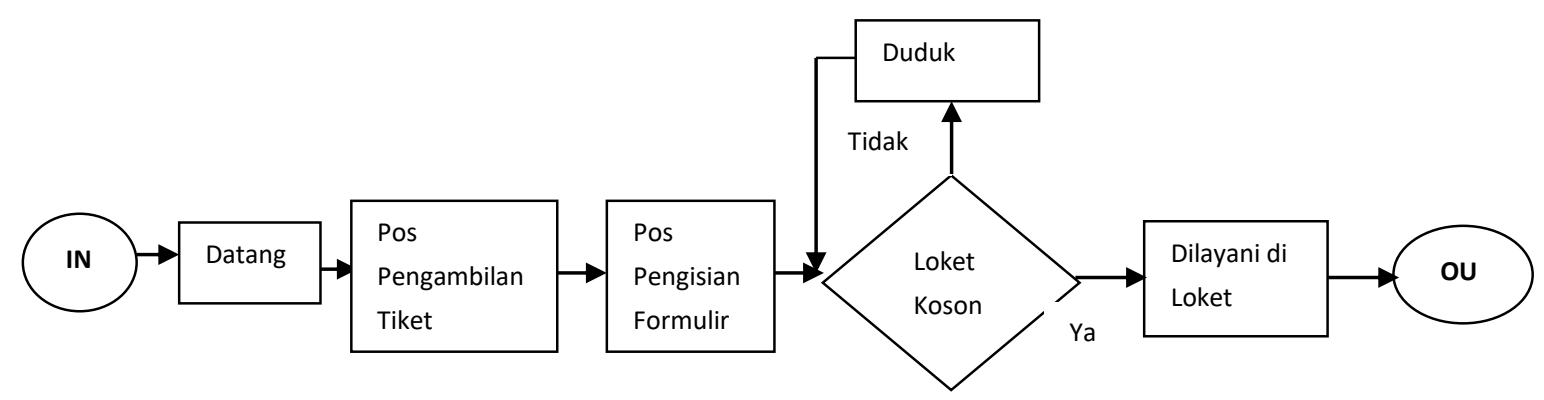

Gambar 4. Proses Simulasi Pemesanan Tiket Kereta Api

\section{Model Simulasi}

Simulasi pada proses reservasi tiket kereta api (KA) terdiri dari beberapa tahapan kegiatan, yaitu: pengambilan ambil tiket (jam mulai, jam berakhir, waktu yang dibutuhkan), pengisian formulir (jam mulai, jam berakhir, waktu yang dibutuhkan), duduk/antri (jam mulai, jam berakhir, waktu yang dibutuhkan), dilayani di loket (jam mulai, jam berakhir, waktu yang dibutuhkan) dan pulang setelah dilayani. Bentuk model simulasi ditunjukkan pada gambar 5 . 


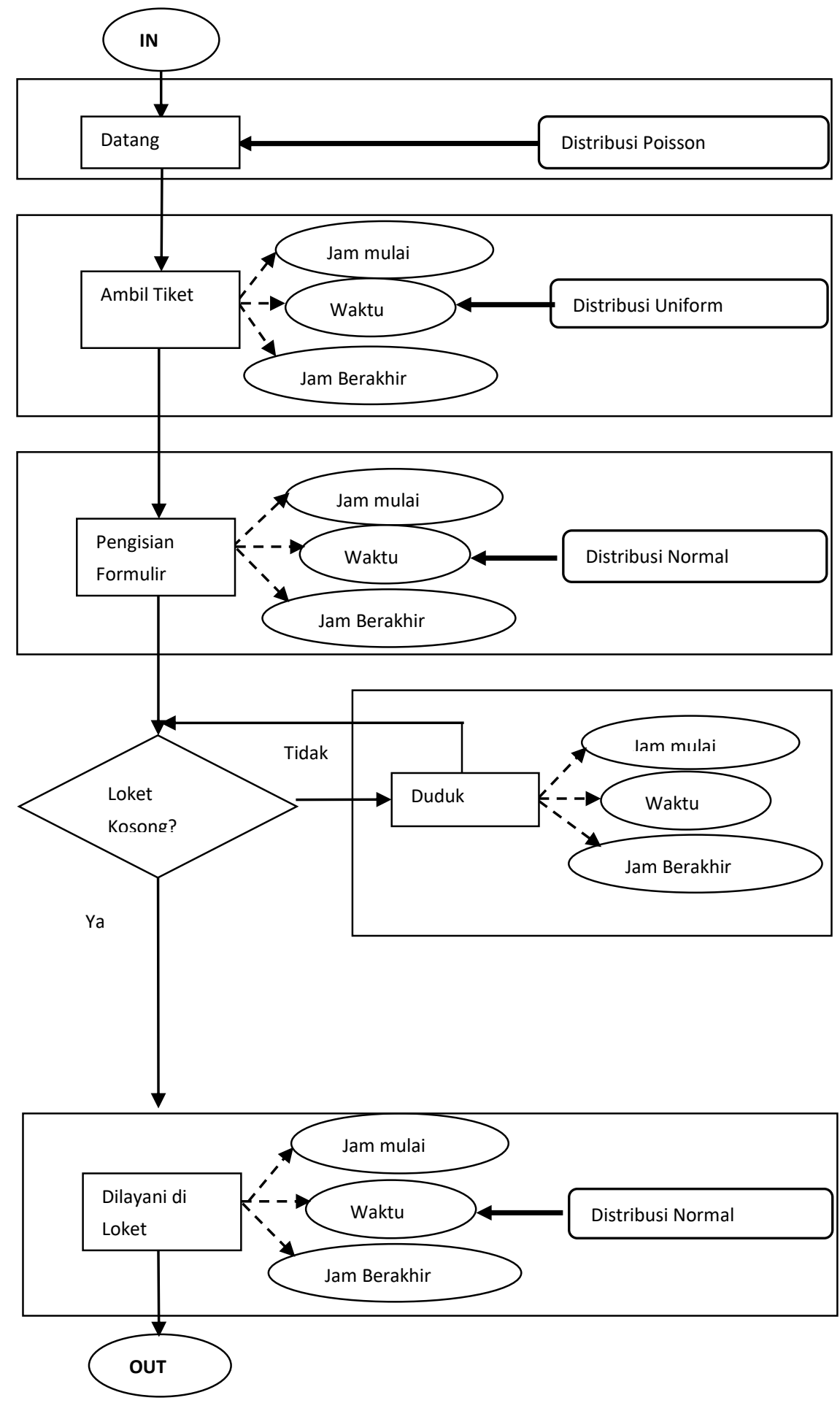

Gambar 5. Proses Pemesanan Tiket Kereta Api 


\section{Jenis Distribusi yang Ditentukan dari Tiap-Tiap Proses Kegiatan Pemesanan Tiket}

Data yang digunakan pada perhitungan simulasi ini adalah data yang ditentukan dengan asumsi jumlah penumpang yang datang untuk melakukan reservasi tiket kereta api (KA) sebesar 20 orang saja. Distribusi selang waktu kedatangan (headway) ditentukan mengikuti Distribusi Poisson dengan $\lambda$ sebesar 3 menit dan ditunjukkan pada Tabel-Gambar 1. Distribusi waktu pengambilan tiket ditentukan mengikuti Distribusi Titik dengan t sebesar 1 menit dan ditunjukkan pada Tabel-Gambar 2. Distribusi waktu pengisian formulir ditentukan mengikuti Distribusi Normal dengan $\mu$ sebesar 4 menit dan ditunjukkan pada Tabel-Gambar 3. Distribusi waktu dilayani di loket ditentukan mengikuti Distribusi Normal yang ditentukan dengan $\mu$ sebesar 7 menit dan ditunjukkan pada Tabel-Gambar 4.

\begin{tabular}{cc}
\hline $\begin{array}{c}\text { Headway } \\
\text { (menit) }\end{array}$ & $\begin{array}{c}\text { Jumlah Penumpang } \\
\text { (orang) }\end{array}$ \\
\hline 1 & 5 \\
2 & 8 \\
3 & 3 \\
4 & 2 \\
5 & 2 \\
\hline Total & $\mathbf{2 0}$ \\
\hline
\end{tabular}

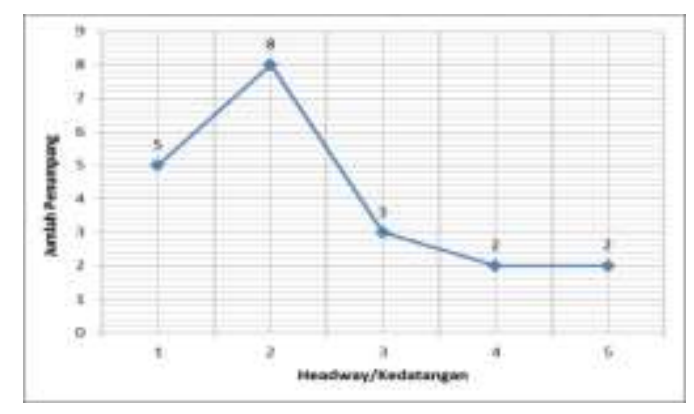

Tabel-Gambar 1. Distribusi Selang Waktu Kedatangan (Distribusi Poisson)

\begin{tabular}{cc}
\hline $\begin{array}{c}\text { Jumlah } \\
\text { Penumpang } \\
\text { (orang) }\end{array}$ & $\begin{array}{c}\text { Waktu Ambil Tiket } \\
\text { (menit) }\end{array}$ \\
\hline 20 orang & 1 \\
\hline
\end{tabular}

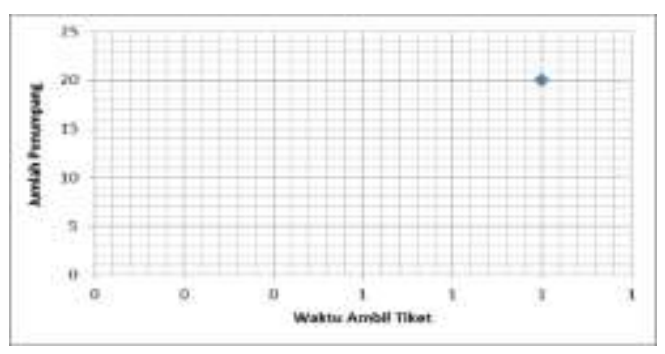

Tabel-Gambar 2. Distribusi Waktu Pengambilan Tiket (Distribusi Titik)

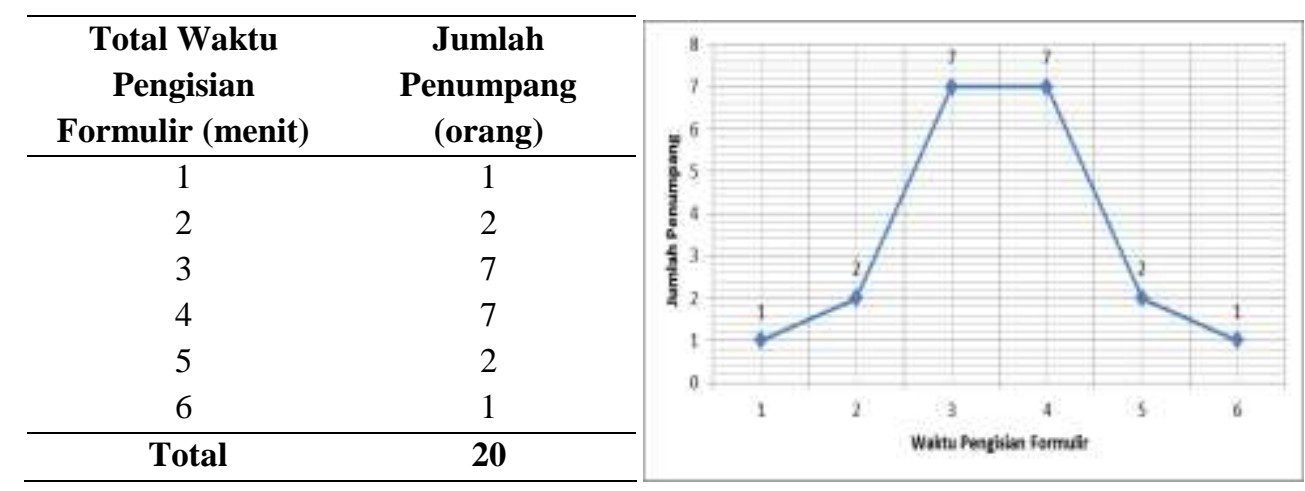

Tabel-Gambar 3. Distribusi Waktu Pengisian Formulir (Distribusi Normal) 


\begin{tabular}{cc}
\hline $\begin{array}{c}\text { Total Waktu } \\
\text { Dilayani di } \\
\text { Loket (menit) }\end{array}$ & $\begin{array}{c}\text { Jumlah } \\
\text { Penumpang } \\
\text { (orang) }\end{array}$ \\
\hline 3 & 1 \\
4 & 1 \\
5 & 2 \\
6 & 6 \\
8 & 6 \\
9 & 2 \\
10 & 1 \\
11 & 1 \\
\hline Total & $\mathbf{2 0}$ \\
\hline
\end{tabular}

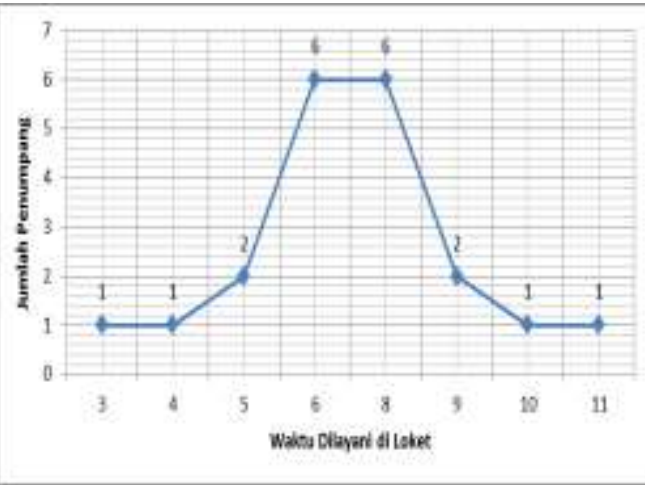

Tabel-Gambar 4. Distribusi Waktu Dilayani di Loket (Distribusi Normal)

\section{Penerapan Simulasi Pada Program Excel}

Pada simulasi perhitungan tempat duduk yang dibutuhkan oleh reservasi tiket kereta api (KA) dilakukan dengan bantuan program excel. Pada program excel, banyaknya cell/kolom yang ada diisi sesuai dengan proses yang harus dilalui bagi pemesan tiket kereta api mulai dari proses masuk (IN) sampai keluar (OUT) stasiun. Pada gambar 6 ditunjukkan tabel excel yang masih kosong dan akan digunakan pada simulasi perhitungan tempat duduk.

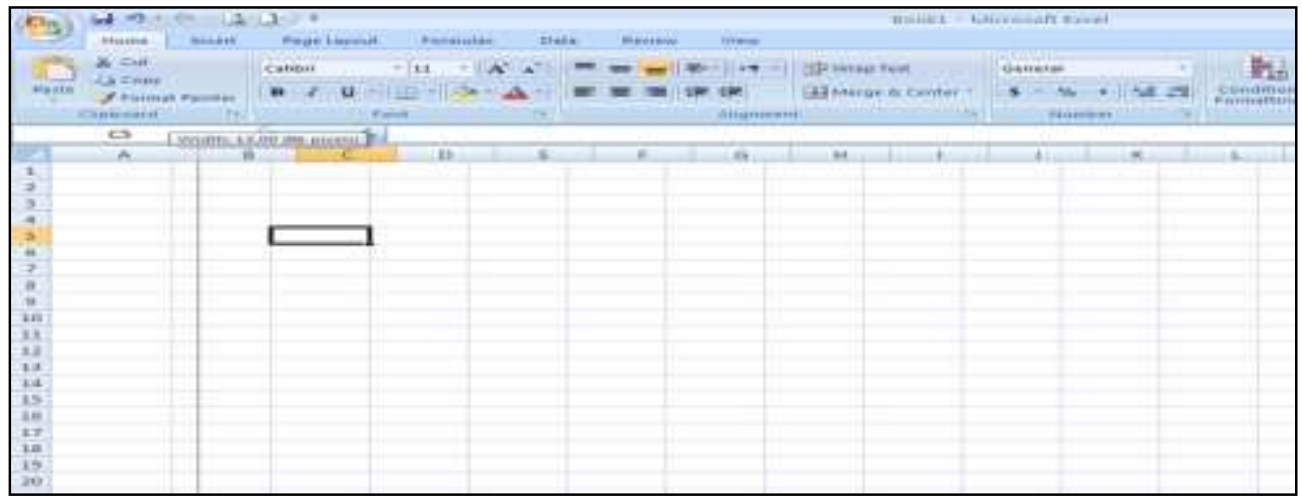

Gambar 6. Tabel Excel yang digunakan Pada Simulasi

\section{Pengisian Judul Pada Tiap-Tiap Kolom}

Simulasi perhitungan tempat duduk yang dikerjakan pada kolom excel dibagi dalam 7 tahapan pada kolom utama dan masih dibagi lagi dalam 22 kolom pendukung (kolom kecil) mengenai hal-hal yang sangat berkaitan dengan perhitungan tempat duduk. Kolom utama terdiri dari kolom 1 (waktu tiba), kolom 2 (ambil tiket), kolom 3 (pengisian formulir), kolom 4 (duduk?), kolom 5 (jumlah orang yang antri), kolom 6 (dilayani di loket), kolom 7 (rekapitulasi). Kolom pendukung berisi tentang Headway (2), Pukul Kedatangan (3), Total Waktu Ambil Tiket (4), Mulai Pukul (5), Berakhir Pukul (6), Total Waktu Pengisian Formulir (7), Mulai Pukul (8), Berakhir Pukul (9), Selisih Jam Pulang dengan Jam Akhir Pengisian Formulir (10), Duduk atau tidak duduk? (11), Mulai Duduk Pukul (12), Berakhir Duduk Pukul (13), Total Waktu Duduk (14), Jumlah Orang Yang Duduk (15), Total Waktu Dilayani di Loket (16), Mulai Pukul (17), Berakhir Pukul (18), Jam Tiba (19), Jam Pulang (20),Total Waktu (21), Keterangan (22) dan ditunjukkan pada gambar 7. 


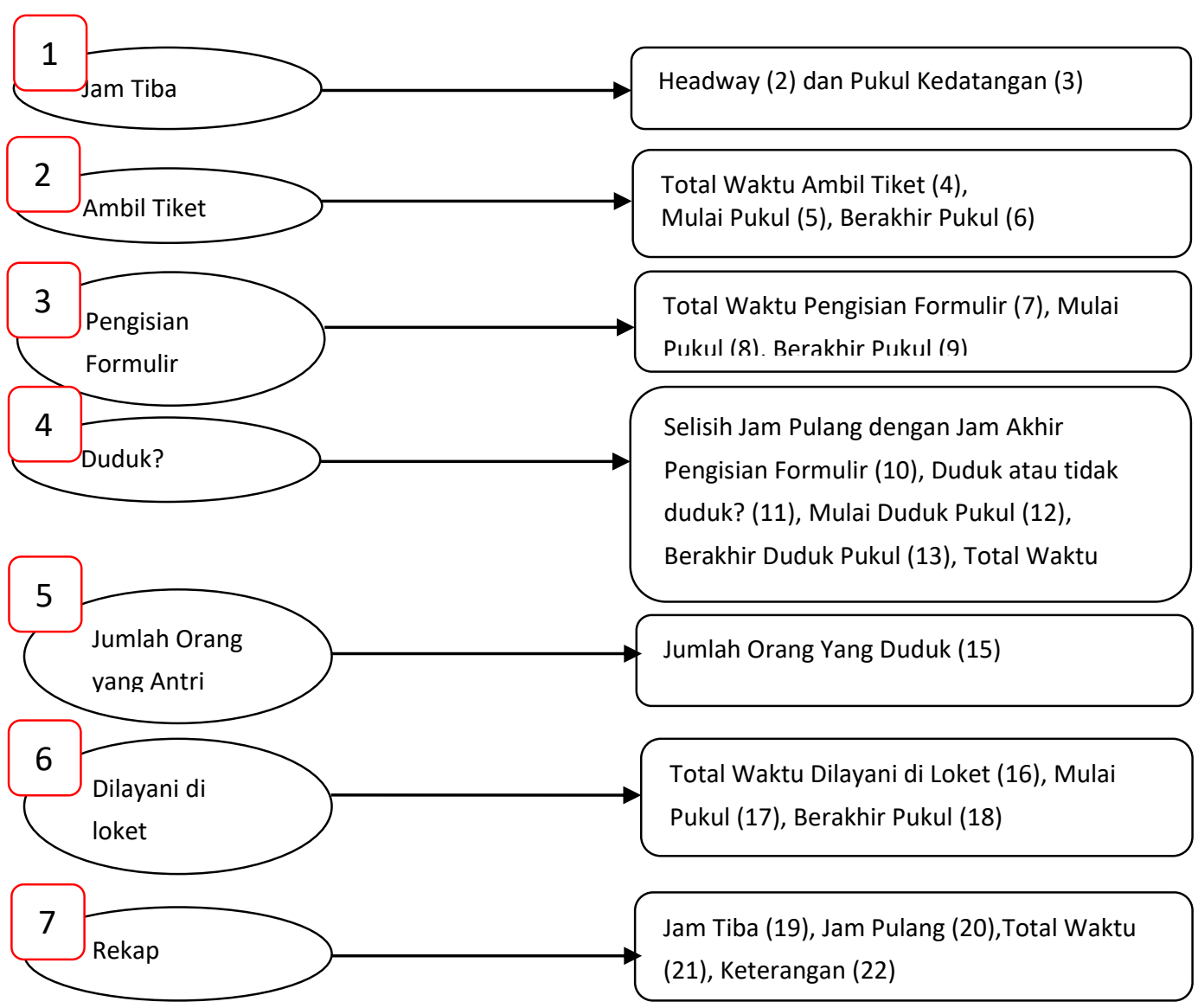

Gambar 7. Judul Pada Kolom Utama dan Kolom Pendukung

\section{Fungsi Excel yang Digunakan dalam Perhitungan Tiap-Tiap Kolom}

Pengisian data pada tiap-tiap kolom excel dilakukan secara otomatis. Data yang diisikan mulai dari kolom 1 sampai dengan kolom 22 berbeda-beda cara pengisiannya. Pada kolom 2,4,7,16 pengisian data dilakukan dengan menggunakan fungsi randbetween. Pada kolom 3,6,9,10,14,17,18,21 pengisian data dilakukan dengan cara penjumlahan dan pengurangan. Pada kolom 11,12,13,15,22 pengisian data dilakukan dengan menggunakan fungsi IF. Perbedaan pengisian data pada tiap-tiap kolom ditunjukkan pada gambar 8 .

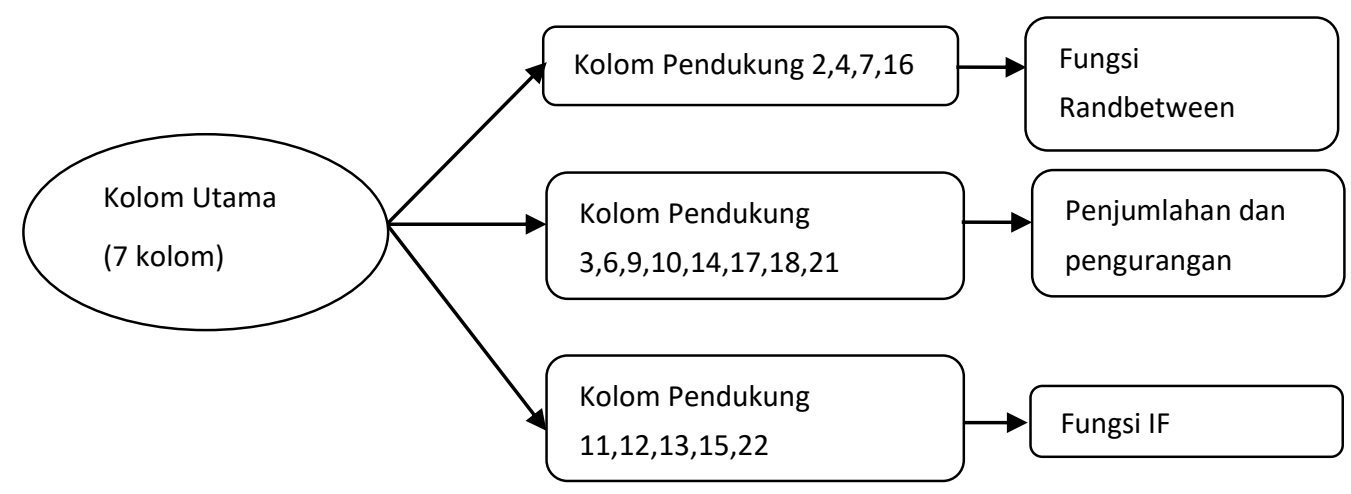

Gambar 8. Fungsi Excel yang Digunakan Pada Tiap-Tiap Kolom 


\section{Hasil Simulasi Perhitungan Tempat Duduk Pada Program Excel}

Simulasi ini dilakukan dengan pembagian beberapa kolom yang terdiri dari jam tiba, ambil tiket, mengisi formulir, duduk atau tidak duduk?, jumlah orang yang duduk, dilayani di loket, dan rekap yang ditunjukkan pada tabel 2. Pada simulasi ini pos tiket, pos pengisian formulir, dan loket penjualan diasumsikan hanya tersedia 1 unit saja. Perhitungan simulasi dilakukan untuk mengetahui jumlah kebutuhan kursi apabila terdapat 20 orang yang datang ke stasiun untuk melakukan reservasi tiket kereta api (KA). Hasil perhitungan diketahui bahwa dari 20 orang yang datang hanya 2 kursi saja yang dibutuhkan selama proses reservasi tiket KA.

Tabel 2. Metoda Simulasi Perhitungan Kebutuhan Jumlah Tempat Duduk Bagi Pemesan Tiket Kereta Api

\begin{tabular}{|c|c|c|c|c|c|c|c|c|c|c|c|c|c|c|c|c|c|c|c|c|c|}
\hline \multirow{2}{*}{$\stackrel{0 \pi}{0}$} & \multicolumn{2}{|c|}{ Aan 10} & \multicolumn{3}{|c|}{ Amathet } & \multicolumn{3}{|c|}{ Whegerentiv } & \multicolumn{5}{|c|}{ Detal ans tak Dant } & \multirow{2}{*}{ 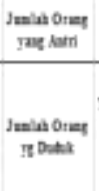 } & \multicolumn{3}{|c|}{ Dhyreit thet } & \multicolumn{4}{|c|}{ Ritw } \\
\hline & 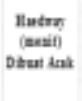 & Risl & $\begin{array}{c}\text { Dotal Galitu } \\
\text { (mente) }\end{array}$ & $\begin{array}{l}\text { Mani } \\
\text { ratal }\end{array}$ & $\begin{array}{l}\text { Garuktz } \\
\text { hate }\end{array}$ & 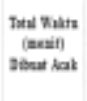 & $\begin{array}{l}\text { Hate } \\
\text { ruth }\end{array}$ & $\begin{array}{l}\text { Sulatir } \\
\text { Putal }\end{array}$ & 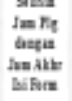 & $\begin{array}{l}\text { Detat } \\
\text { atas tida } \\
\text { detak? }\end{array}$ & 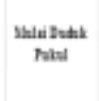 & 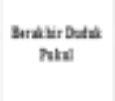 & $\begin{array}{l}\text { Jotal } \\
\text { wati } \\
\text { Dotak }\end{array}$ & & 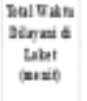 & $\begin{array}{l}\text { Yani } \\
\text { ratal }\end{array}$ & $\begin{array}{l}\text { Surutur } \\
\text { nutal }\end{array}$ & The & $\begin{array}{c}\text { Las } \\
\text { rang }\end{array}$ & $\begin{array}{c}\text { Dal } \\
\text { Watu } \\
\text { navien } \\
\text { Thit }\end{array}$ & 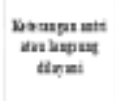 \\
\hline \multirow[t]{2}{*}{1} & 2 & 1 & 4 & i & 6 & + & 1 & 1 & it & u & 12 & II & 4 & 15 & 46 & 19 & II & $z$ & $n$ & 21 & II \\
\hline & o govats & $5^{-1}+2$ & oroukas & 1 & 54 & orovats & i & $y$ & $2+-1$ & 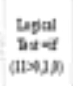 & $\begin{array}{l}\text { Legaxint } \\
\text { afllows }\end{array}$ & 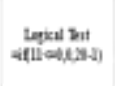 & 124 & 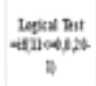 & oxaums & Hu & Helt & 3 & แ & thato & 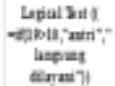 \\
\hline 1 & 100 & 160 & 98 & 200 & $m$ & 180 & 6 & tif & 366 & t & 100 & 100 & $3 \%$ & 1 & +100 & 20 & 6017 & $\omega 0$ & 100 & ex &. \\
\hline t & 151 & 68. & ow: & $\mathrm{sm}$ & as: & 124 & 62 & $6 \mathbb{x}$ & aer & 1 & is & ax & ts6 & 2 & at & is & 60 & oll & is & 815 & 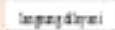 \\
\hline$:$ & ist & :4 & in & se & is & 124 & $m$ & cis & tet: & t & in & in & 20 & $t$ & $2 x$. & 10 & an & tes & $a$ & क⿱⿻一⿻口卄日乀木 & Ingagirei \\
\hline 3 & 10 & sa & one & 108 & is & 198 & $\theta$ & ets & 264 & z & (I) & แ & เม & 3 & ats. & 10 & $6: 3$ & ail & 635 & an & atti \\
\hline , & 204 & If & $\omega \omega^{\circ}$ & ร15 & nt & ist & Ali & (4) & in & : & $2 \pi$ & in & stit & i & $2 \pi$ & 00 & 2N & A17 & nt & or & \pm \\
\hline 5 & 14. & H4 & on: & at & iII & 121 & etH & IIII & L4) & 1 & III & $\Psi$ & us & 3 & ane & $\omega$ & tell & 63 & tat & oll & $= \pm t r i$ \\
\hline . & in & 27 & $m$ & $\mathrm{NH}$ & iII & 608 & as & (2) & 13) & 8 & 13 & te & เ23 & 3 & 780 & to & at. & का & :211 & 64 & $w i$ \\
\hline 7 & 191 & til & til & $\mathrm{kH}$ & 618 & 121 & 48 & 62 & uI & $x$ & 44 & 4.5 & t!! & 1 & ifit & is & $\mathrm{EA}$ & ais & Ga & bet & atri \\
\hline 8 & 104 & ia & on & s & 121: & $m$ & af & क्म & 34 & I & tit & t & 27 & F & $b x$ & ts & 85 & $62 x$ & 198 & 20. & 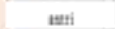 \\
\hline 1 & 14 & 24 & ots. & 613 & is & 101 & trt & est & 204 & I & tis & 134 & 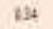 & I & 4II & es & 68 & tat & 64. & tof & I \\
\hline 11 & tat & 13 & 050 & III & 635 & 101 & tn & t) & 36 & t & 63 & 13 & tet & $z$ & or & 03 & 50 & 831 & sม & 791 & 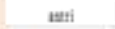 \\
\hline 4 & iti & in & in & s]2 & ifI & 14 & cal & tat & Itt & ff & 2.4 & in & 14 & 1 & III & in & in & (III & the & 24 & atri \\
\hline 18 & 19 & 17 & Q6es & sn & (3) & 101 & 63: & es & ase & 3 & 14 & in & 26 & I & 224 & 10 & SA & (a) & 69 & का & 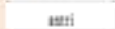 \\
\hline 11 & 194 & 635 & ats & sai & tet & 601 & te & te & tu & 1 & 14.4 & in & tes & 1 & we & 13.4. & all & $G$ & 68 & 64 & Itri \\
\hline 14 & 108 & 14 & OD & $3 H$ & (N) & in & (4) & en & in & I & or & I & Is: & 1 & QII & 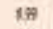 & $7 n$ & $\mathrm{BH}$ & 78 & 93 & \pm \\
\hline II & ta & (4) & ow & (4) & iA & ins & tat & $t 8$ & tit & 1 & 106 & $M$ & is & $i$ & OSt & 208 & $9 x$ & th & 98 & 63 & i \\
\hline 17 & 104 & in & ant & sts & (5) & 10t: & $45 \pi$ & ts & $\mu t$ & I & $\mathrm{ma}$ & $7 \%$ & 14 & 7 & 48 & 78 & 714 & on & $T H$ & in & wti \\
\hline It & 101 & 63 & oest & is & 134 & 184 & ASH & $\$ 8$ & HE & : & 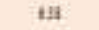 & th & ts. & 1 & $\Delta x$ & 424 & 73 & (ii) & tai & ot & Itri \\
\hline 18 & 101 & 184 & in & 34 & 158 & in & (5) & ts & IAH & 8 & in & 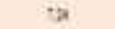 & $2 s t$ & $i$ & 10 & 19 & 1) & est & (3) & क7 & 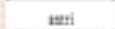 \\
\hline 41 & tht & 294 & ots & Eat & \pm 2 & 107 & 48 & 48 & 484 & I & is & to & $15 \%$ & $y=$ & otl. & $w$ & te & tis & 84 & bII & atri \\
\hline u & iot & $1 m$ & An & 560 & $t n$ & int & sit & $\theta$ & 172 & $t$ & 186 & 74 & (7) & $i$ & in & ta & 7 & 100 & $+H$ & 62 & \pm \\
\hline
\end{tabular}

\section{KESIMPULAN}

Proses simulasi perhitungan tempat duduk dengan asumsi 20 orang yang melakukan pemesanan tiket kereta api menghasilkan beberapa hal sebagai berikut:

- Tahapan-tahapan yang harus dilalui bagi pemesan tiket kereta api yaitu: datang, pengambilan tiket antrian, pengisian formulir, cek loket, loket kosong dapat langsung dilayani, loket penuh harus duduk/antri terlebih dahulu, setelah selesai dilayani di loket reservasi tiket kereta api kemudian keluar dari stasiun.

- Distribusi headway kedatangan ditentukan mengikuti Distribusi Poisson dengan $\lambda$ sebesar 3 menit.

- Distribusi waktu pengambilan tiket ditentukan mengikuti Distribusi Titik dengan t sebesar 1 menit.

- Distribusi waktu pengisian formulir ditentukan mengikuti Distribusi Normal dengan $\mu$ sebesar 4 menit.

- Distribusi waktu dilayani di loket mengikuti Distribusi Normal yang ditentukan dengan $\mu$ sebesar 7 menit. 
- Jumlah tempat duduk yang harus disediakan bagi 20 orang pemesan tiket kereta api sejumlah 2 tempat duduk.

Penelitian menghasilkan metoda simulasi bagi perhitungan kebutuhan jumlah tempat duduk berdasarkan data asumsi. Metoda simulasi yang dihasilkan sudah baik. Oleh karena itu diperlukan penelitian lanjutan berupa penerapan metoda simulasi dengan menggunakan data yang sebenarnya.

CATATAN. Penelitian ini dilakukan dengan pengamatan langsung di Stasiun Gubeng terkait dengan pemesan tiket KA. Hasil pengamatan dijadikan dasar dalam penelitian metoda simulasi perhitungan jumlah tempat duduk bagi pemesan tiket.

\section{DAFTAR PUSTAKA}

Butar-Butar, M.B. \& Yamin, M. (2008). "Penggunaan Simulasi Untuk Pemecahan Masalah Transportasi". Prosiding Seminar Ilmiah Nasional Komputer dan Sistem Intelijen (KOMMIT), halaman. 199-205, Universitas Gunadarma, Depok.

Dimyati, T.T. \& Dimyati, A. (1994). Operation Research-Model Pengambilan Keputusan. Sinar Baru Algensindo. Bandung.

Heizer, J. \& Render, B. (2008). Operation Management. Edition 9. Education International. Inc. Saddle River. New Jersey. USA.

Sudjana. (2004). Statistika untuk Ekonomi dan Niaga. Penerbit PT Tarsito. Bandung.

Suprayitno, H. (2017). Statistik. Handout: Metoda Kuantitatif bagi Transportasi. S2 Manajemen dan Rekayasa Transportasi. Jurusan Teknik Sipil. Institut Teknologi Sepuluh Nopember. Surabaya.

Tim Litbang Wahana Komputer. (2017). Kamus Lengkap Formula \& Fungsi Excel. Penerbit Andi \& Penerbit Wahana Komputer. Yogyakarta \& Semarang.

Zulfikarijah, F. (2003). Operation Research. Bayumedia Publishing. Malang. 
